\title{
A combination of lactic acid bacteria regulates Escherichia coli infection and inflammation of the bovine endometrium
}

\author{
Sandra Genís, ${ }^{*}$ Alejandro Sánchez-Chardi,† Àlex Bach, ${ }^{*} \ddagger$ Francesc Fàbregas, ${ }^{*}$ and Anna Arís ${ }^{* 1}$ \\ *Department of Ruminant Production, Institut de Recerca i Tecnologia Agroalimentàries (IRTA), Torre Marimon, Caldes de Montbui, \\ Barcelona, Spain 08140 \\ †Servei de Microscopia, Facultat de Biociències, Campus UAB, Bellaterra, Barcelona, Spain 08193 \\ fInstitució Catalana de Recerca i Estudis Avançats (ICREA), Barcelona, Spain 08010
}

\begin{abstract}
Uterine function in cattle is compromised by bacterial contamination and inflammation after calving. The objective of this study was to select a combination of lactic acid bacteria (LAB) to decrease endometrium inflammation and Escherichia coli infection. Primary endometrial epithelial cells were cultured in vitro to select the most favorable LAB combination modulating basal tissue inflammation and E. coli infection. Supernatants were obtained to determine expression of pro-inflammatory cytokines, and E. coli infection was evaluated after harvesting the tissue and plate counting. The selected LAB combination was tested in uterus explants to assess its capacity to modulate basal and acute inflammation (associated with E. coli infection). The combination of Lactobacillus rhamnosus, Pediococcus acidilactici, and Lactobacillus reuteri at a ratio of 25:25:2, respectively, reduced $E$. coli infection in vitro with $(89.77 \%)$ or without basal tissue inflammation (95.10\%) compared with single LAB strains. Lactic acid bacteria treatment reduced $C X C L 8$ and $I L 1 B$ expression 4.7- and 2.2-fold, respectively, under acute inflammation. Ex vivo, the tested LAB combination reduced acute inflammation under $E$. coli infection, decreasing IL-8, IL-1 $\beta$, and IL-6 up to 2.2-, 2.5-, and 2.2 -fold, respectively. In the total inflammation model, the LAB combination decreased IL-8 1.6-fold and IL-6 1.2-fold. Ultrastructural evaluation of the tissue suggested no direct interaction between the LAB and $E$. coli, although pathological effects of $E$. coli in endometrial cells were greatly diminished or even reversed by the LAB combination. This study shows the promising potential of LAB probiotics for therapeutic use against endometrial inflammation and infection.
\end{abstract}

Received June 28, 2016.

Accepted September 14, 2016.

${ }^{1}$ Corresponding author: anna.aris@irta.cat
Key words: Escherichia coli, endometrium, inflammation, lactic acid bacteria

\section{INTRODUCTION}

Uterine function is often compromised in cattle by bacterial contamination and inflammation after calving (Markusfeld, 1987; Borsberry and Dobson, 1989; Opsomer et al., 2000). Metritis is an acute inflammation that occurs within $21 \mathrm{~d}$ and is most common within the first $6 \mathrm{~d}$ after parturition. Metritis affects about $20 \%$ of lactating dairy cows, with an incidence ranging from 8 to $>40 \%$ (Galvão, 2011), and is characterized by an enlarged uterus and a watery red-brown fluid discharge, which has a fetid odor (Sheldon et al., 2009). When a persistent clinical disease is found $3 \mathrm{wk}$ after calving, the process is described as purulent vaginal discharge ( $\sim 20 \%$ incidence). However, about $30 \%$ of dairy cows have subclinical endometritis (Markusfeld, 1987; Borsberry and Dobson, 1989; Opsomer et al., 2000; Drillich et al., 2001; Sheldon et al., 2006; Lincke et al., 2007), and thus the problem may occur unnoticed. The economic effect of uterine diseases in dairy cows is derived from infertility, increased culling due to failure to conceive, reduced milk production, and the cost of antibiotic treatments. The economic cost of a single case of metritis has been calculated to be about $€ 350$ (Drillich et al., 2001; Overton and Fetrow, 2008).

Among the wide range of bacteria that contaminate the bovine uterus, Escherichia coli are abundant and are associated with high concentrations of LPS in the uterine lumen and with metritis (Williams et al., 2005). Bacterial infection is generally considered to foster the recruitment of immune cells and lead to acute inflammation in the uterus (Herath et al., 2006). This process coexists with postpartum uterine involution, which causes basal tissue inflammation, leading to an excessive inflammatory status. In some cases, the persistent inflammatory response is also attributable, in part, to reduced immune function before calving (LeBlanc, 2014). In this context, efforts to reduce uterine infec- 
tion and the consequent acute inflammation are of great importance to decrease the final inflammatory status of the uterus and its side effects such as tissue damage or failure to complete involution of the uterus (Walker et al., 2015).

The mechanisms of infection and immunity in the endometrium have mostly been studied in vitro (Herath et al., 2006; Sheldon et al., 2009), whereas the characterization of uterine infection and insights into the pathogenesis of disease often stem from observational studies of spontaneous postpartum uterine infections in vivo (Borsberry and Dobson, 1989; Opsomer et al., 2000; Drillich et al., 2001). The overall inflammatory response to pathogens associated with innate immunity depends on the sum of the actions of multiple cell types rather than just specialized immune cells (Sheldon et al., 2014). The study of tissue explants collected from the endometrium ex vivo allows investigation of potential links between whole-animal clinical signs and cellular function (Borges et al., 2012). Inflammatory mediators, such as cytokines, are important molecules eliciting the cellular response against pathogens, but they also may initiate a cascade of events that may end in important toxic effects on the tissue or induce cell death by necrosis or apoptosis. In this context, morphological assessment of toxic effects at the ultrastructural level by field emission scanning electron microscopy (FESEM) and transmission electron microscopy (TEM) are valuable tools to understand how $E$. coli alone or combined with LAB affects cell health.

Because the traditional antimicrobial treatment applied for metritis may lack efficacy and does not typically improve reproductive performance of the treated animals (Gilbert and Schwark, 1992; Otero et al., 2006), the use of probiotic strains of bacteria has been proposed as an alternative to prevent postpartum uterine infections and inflammation (Ametaj et al., 2014; Deng et al., 2015). In our recent work, various individual strains of LAB were shown to protect against $E$. coli infection in vitro and reduce inflammation in epithelial cells (Genís et al., 2016). The hypothesis of the present work is that the combination of LAB strains tested in our previous work (Genís et al., 2016) could reduce inflammation and E. coli infection in bovine endometrium. Ex vivo experiments offer a good opportunity to evaluate these effects considering the combination of several cell types and their interactions.

The objective of this study was to establish the best probiotic combination of Lactobacillus rhamnosus, Pediococcus acidilactici, and Lactobacillus reuteri in primary cultures and to assess its capacity to modulate of the uterine inflammation caused by basal tissue inflammation, such as that associated with calving, or by acute factors such as $E$. coli infection.

\section{MATERIALS AND METHODS}

\section{Bacterial Strains and Culture Conditions}

Pediococcus acidilactici (CECT 5915) and L. rhamnosus (CECT 278) were purchased from CECT (Colección Española de Cultivos Tipo, CSIC Valencia, Spain). Lactobacillus reuteri (DSM 20016) and Lactobacillus sakei (DSM 20100) were acquired from DSMZ (German collection of microorganisms and cell cultures, Leibniz, Germany). A swab sample was taken from the uterus of 4 metritic cows to isolate a pathogenic E. coli. Each swab was spread in blood agar, MacConkey agar, and chocolate agar. Final identification of the colonies was made by Vitek (bioMérieux, Craponne, France). The $E$. coli selected was FimH positive (virulence factor) and hemolytic. Bacterial cultures were iniated by inoculating $1 \mathrm{~mL}$ of a glycerinate in $9 \mathrm{~mL}$ of Luria Bertani medium (10 g/L peptone, $5 \mathrm{~g} / \mathrm{L}$ yeast extract, and 10 $\mathrm{g} / \mathrm{L} \mathrm{NaCl}$ ) for E. coli or de Man, Rogosa, and Sharpe medium (Scharlau, Sentmenat, Spain) for L. rhamnosus, $P$. acidilactici, and L. reuteri at $37^{\circ} \mathrm{C}$ in static conditions overnight $(\mathbf{O} / \mathbf{N})$. Then, bacteria were centrifuged at $6,000 \times g$ for 15 min and resuspended at $1 \times$ $10^{8} \mathrm{cfu} / \mathrm{mL}$ with Dulbecco's modified Eagle's medium (DMEM, Gibco, New York, NY) supplemented with $8 \mu \mathrm{g} / \mathrm{mL}$ bovine insulin and $50 \mu \mathrm{g} / \mathrm{mL}$ hydrocortisone. Escherichia coli concentration $(\mathrm{cfu} / \mathrm{mL}$ ) was confirmed by serially diluting and plating into MacConkey (Scharlau, Sentmentat, Spain) agar medium. Colonies were counted after $\mathrm{O} / \mathrm{N}$ growth at $37^{\circ} \mathrm{C}$.

\section{Endometrial Primary Culture}

Endometrial tissue was obtained at a slaughterhouse from postpubertal nonpregnant cattle with no evidence of genital disease or microbial infection and transported in chilled PBS with $100 \mu \mathrm{g} / \mathrm{mL}$ streptomycin, $100 \mathrm{U} / \mathrm{mL}$ penicillin, and $2.5 \mu \mathrm{g} / \mathrm{mL}$ amphotericin $\mathrm{B}$ (PEF) to the laboratory. Tissue was then cut into small pieces and incubated with PBS supplemented with $1 \times$ PEF, $0.1 \mathrm{~m} M$ EDTA, and $0.1 \mathrm{~m} M$ DTT for $10 \mathrm{~min}$ at $37^{\circ} \mathrm{C}$ in $5 \% \mathrm{CO}_{2}$ at $200 \mathrm{rpm}$. The supernatant was removed, and RPMI 1640 medium (Gibco) with $0.25 \%$ collagenase (Gibco) was added and further incubated for $15 \mathrm{~min}$ at $37^{\circ} \mathrm{C}$ in $5 \% \mathrm{CO}_{2}$ at $200 \mathrm{rpm}$. Supernatant was collected and mixed (1:1) with RPMI 1640 medium enriched with $0.02 \mathrm{mg} / \mathrm{mL}$ DNase (Roche, Mannheim, Germany). Cells present in the supernatant were recovered after centrifuging 5 min at $300 \times g$. This process was repeated 3 times. Final cell pellets were resuspended in DMEM with $8 \mu \mathrm{g} / \mathrm{mL}$ bovine insulin, $10 \mu \mathrm{g} / \mathrm{mL}$ gentamycin, $50 \mu \mathrm{g} / \mathrm{mL}$ hydrocortisone, 50 $\mu \mathrm{g} / \mathrm{mL}$ streptomycin, $50 \mathrm{IU} / \mathrm{mL}$ penicillin, $2.5 \mu \mathrm{g} /$ 
$\mathrm{mL}$ amphotericin $\mathrm{B}$, and $10 \mathrm{ng} / \mathrm{mL}$ epithelial growth factor (Sigma-Aldrich, St. Louis, MO). Hydrocortisone was included in the medium to foster cell growth (Domènech et al., 2014). Cells were quantified using a hemocytometer and incubated at 160,000 cells $/ \mathrm{cm}^{2}$ in culture flasks. Epithelial cell phenotype was confirmed by immunofluorescence labeling against anticytokeratin (monoclonal anti-cytokeratin pan antibody produced in mouse, 1:500 dilution; Sigma-Aldrich) of at least $90 \%$ of isolated cells as previously shown (Genís et al., 2016). For the immunofluorescence, endometrial primary cells were grown on coverslips and fixed with $4 \%$ paraformaldehyde in PBS. HeLa cells were used as a positive control, and macrophage differentiated THP1 cells as a negative control. Coverslips were blocked with $150 \mu \mathrm{L}$ of PBS containing goat serum $(0.05 \% \mathrm{vol} /$ vol) and Triton $0.2 \%$ for $30 \mathrm{~min}$ at room temperature. The primary antibody was incubated in blocking buffer for $2 \mathrm{~h}$ at room temperature at a dilution of 1:500 (monoclonal anti-cytokeratin pan antibody produced in mouse; Sigma-Aldrich). After 3 washes with PBS, secondary antibody, an anti-mouse-fluorescein isothiocyanate, was incubated for $1 \mathrm{~h}$ at room temperature at a dilution of 1:1,000 (Sigma-Aldrich). Last, cells were washed and dried coverslips mounted on glass slides using Fluoroprep (Biomerieux, Craponne, France) and observed by fluorescence microscopy.

\section{Ex Vivo Bovine Endometrial Explants}

Segments of endometrial tissue were obtained at a slaughterhouse from 20 postpubertal nonpregnant cattle with no evidence of genital disease or microbial infection and transported in chilled PBS with $100 \mu \mathrm{g} /$ $\mathrm{mL}$ streptomycin, $100 \mathrm{U} / \mathrm{mL}$ penicillin, and $2.5 \mu \mathrm{g} /$ $\mathrm{mL}$ amphotericin $\mathrm{B}$ to the laboratory. The tissue was cut into $0.8-\mathrm{cm}^{2}$ diameter segments using skin biopsy punches (Kai Medical, Seki, Japan). The explants were plated in 24-well plates (1 explant/well) and incubated with RPMI 1640 medium (Gibco) supplemented with

Table 1. Combinations of lactic acid bacteria (LAB; Lactobacillus rhamnosus, Pediococcus acidilactici, and Lactobacillus reuteri) assessed in vitro for their ability to reduce inflammation and infection with Escherichia coli in a uterine explant model for dairy cows ${ }^{1}$

\begin{tabular}{lccc}
\hline & \multicolumn{3}{c}{ Ratio } \\
\cline { 2 - 4 } Combination & L. rhamnosus & P. acidilactici & L. reuteri \\
\hline $\mathrm{A}$ & 100 & 25 & 0 \\
$\mathrm{~B}$ & 25 & 25 & 0 \\
$\mathrm{C}$ & 100 & 25 & 2 \\
$\mathrm{D}$ & 25 & 25 & 2 \\
\hline
\end{tabular}

${ }^{1}$ Ratio of each LAB corresponds to the number of LAB vs. endometrial epithelial cells.
$10 \% \mathrm{FBS}, 50 \mu \mathrm{g} / \mathrm{mL}$ streptomycin, $50 \mathrm{IU} / \mathrm{mL}$ penicillin, and $2.5 \mu \mathrm{g} / \mathrm{mL}$ amphotericin $\mathrm{B}$ in $5 \% \mathrm{CO}_{2}$ at $37^{\circ} \mathrm{C}$. These experiments were repeated on 4 different days (each day involving 5 independent animals to reach a total of 20 cows) and using in each experiment 6 replicates/animal for each ex vivo treatment. Sample size was established taking into account the animal variability observed in previous gene expression and ex vivo experiments (data not shown)

\section{In Vitro Experiments: LAB Treatment, Inflammation, and E. coli Infection}

Primary epithelial cells were plated at 80,000 cells/ well in 24-well plates with DMEM supplemented with $8 \mu \mathrm{g} / \mathrm{mL}$ bovine insulin and $50 \mu \mathrm{g} / \mathrm{mL}$ hydrocortisone and kept $\mathrm{O} / \mathrm{N}$ at $37^{\circ} \mathrm{C}$ and $5 \% \mathrm{CO}_{2}$. Cells were incubated with 6 replicates $\mathrm{O} / \mathrm{N}$ with 4 LAB combinations (Table 1 ) and positive controls ( $P$. acidilactici at a ratio of 25 bacteria/epithelial cell, in the model without basal inflammation, and with $L$. reuteri at ratio of 2 bacteria/endometrial cell, in the presence of basal inflammation). The basal inflammation was induced with $10 \mu \mathrm{g} / \mu \mathrm{L}$ of IL-1 $\beta$ as described elsewhere (Genís et al., 2016). Cells were then challenged with $4 \times 10^{6} \mathrm{cfu} /$ well of $E$. coli for $6 \mathrm{~h}$. Infection without LAB was used as an infection control and incubation with medium instead of $E$. coli as a negative control. If cells were submitted to previous basal inflammation, the negative control was cells with IL-1 $\beta$ and medium. Cells were washed twice with chilled PBS, and associated bacteria were released with $500 \mu \mathrm{L}$ of $0.9 \% \mathrm{NaCl} /$ well. Associated $E$. coli was quantified by serially diluting and plating the cell extract onto MacConkey agar media. Colonies were counted after $\mathrm{O} / \mathrm{N}$ growth at $37^{\circ} \mathrm{C}$. Cells used for gene expression analyses were washed twice with PBS and harvested with $500 \mu \mathrm{L}$ of TriZol (5Prima, Gaithersburg, MD) for RNA extraction.

\section{Ex Vivo Experiments: LAB Treatment, Inflammation, and E. coli Infection}

Explants were incubated in 6 replicates $\mathrm{O} / \mathrm{N}$ with the selected LAB combination and then challenged with 1.5 $\times 10^{6} \mathrm{cfu} /$ well of $E$. coli $\mathrm{O} / \mathrm{N}$. Infection without LAB was used as an infection control and incubation with media instead of $E$. coli as a negative control. When $E$. coli infection was evaluated in endometrial explants under inflammation, IL-1 $\beta$ was added at $10 \mathrm{ng} /$ well $1 \mathrm{~h}$ before LAB administration. In this case explants inflamed and infected were used as an infection control, and explants inflamed and treated with LAB were used as a negative control. Supernatant was collected for further IL-8, IL-1 $\beta$, and IL-6 ELISA quantification. 


\section{Quantitative RT-PCR Analyses}

One microgram of RNA was reverse transcribed to cDNA using the PrimeScript RT reagent kit (Takara, Shiga, Japan) following manufacturer's instructions. Quantitative PCR (qPCR) was performed for bovine $C X C L 8$ and $I L 1 B$ using specific primers (Table 2). A total reaction volume of $20 \mu \mathrm{L}$ was used, containing $50 \mathrm{ng}$ of cDNA, $10 \mu \mathrm{L}$ of SYBR Green Fluorescent (Bio-Rad, Hercules, CA), and the optimized primer concentration for each gene (Table 2). The qPCR amplifications were cycled as follows: an initial denaturing step of $10 \mathrm{~min}$ at $95^{\circ} \mathrm{C}$, followed by 40 cycles of $10 \mathrm{~s}$ at $95^{\circ} \mathrm{C}, 15 \mathrm{~s}$ at the optimized annealing temperature for each gene, 30 to $60 \mathrm{~s}$ at $72^{\circ} \mathrm{C}$, and a final extension of $10 \mathrm{~min}$ at $72^{\circ} \mathrm{C}$. Relative gene expression was calculated using the Pfaffl method (Pfaffl, 2001) with GAPDH as a reference gene control, and all the qPCR were performed in triplicate. $G A P D H$ was chosen because it is stably expressed in a variety of cells, including uterine tissues (Wathes et al., 2009; Galvão et al., 2011). Moreover, we checked that no differences in the expression of $G A P D H$ were found among treatments.

\section{Enzyme-Linked Immunosorbent Assay}

Concentrations of IL-1 $\beta$, IL-6, and IL-8 were measured in supernatants from explants by sandwich ELISA according to the manufacturers' instructions: Bovine IL-1 $\beta$ ELISA Kit (ESS0027; ThermoFisher Scientific, Cramlington, UK); Bovine IL-6 ELISA Kit (ESS0029; ThermoFisher Scientific); Human CXCL8/ IL-8 DuoSet (DY208, Vitro S.A., Spain). The Human CXCL8/IL-8 DuoSet has previously been validated for measuring bovine IL-8 (Rinaldi et al., 2008; Borges et al., 2012). Bovine IL-1 $\beta$ ELISA Kit and Bovine IL-6 ELISA Kit are specific for the measurement of natural and recombinant IL-1 $1 \beta$ and IL-6, respectively.

\section{Field Emission Scanning Electron Microscopy}

Microdrops of $L$. rhamnosus, P. acidilactici, and $L$. reuteri cultures were directly deposited for 2 min onto silicon wafers (Ted Pella Inc., Redding, CA), excess of sample blotted with Whatman filter, air-dried, and immediately observed without coating in nearly native state with a FESEM Zeiss Merlin (Oberkochen, Germany) equipped with a high resolution in lens secondary electron detector and operating at $1 \mathrm{kV}$.

Triplicate samples of epithelial cell cultures with or without LAB treatment and with E. coli infection, except for the negative control, were fixed with $3 \%$ (vol/ vol) glutaraldehyde (Merck, Darmstadt, Germany) in phosphate buffer (PB) 0.1 M at pH 7.2 (Sigma-Aldrich, Steinheim, Germany) for $2 \mathrm{~h}$ at room temperature, rinsed 4 times with $\mathrm{PB}$, postfixed with $1 \%$ (wt/vol) osmium tetraoxide (TAAB Lab, Reading, UK) in PB for $2 \mathrm{~h}$ at $4^{\circ} \mathrm{C}$, rinsed 4 times in $\mathrm{PB}$, dehydrated in ethanol (Panreac, Barcelona, Spain), and dried with $\mathrm{CO}_{2}$ in a critical point drying system (Bal-Tec AG, Bakzers, Liechtenstein). Samples were mounted on stubs and observed without coating with a Zeiss Merlin microscope under the same conditions as LAB samples.

A qualitative approach was used for the analysis of 10 randomly distributed areas for each treatment. The parameters observed were general structure of the epithelium (size and shape of cells, ultrastructure, and amounts of ultrastructure of microvilli), presence of $E$. coli and LAB on the cell surface, and cell debris.

\section{Transmission Electron Microscopy}

For the assessment of potential changes in the ultrastructure, samples of epithelial cultures treated with PBS, E. coli, and E. coli with $\mathrm{LAB}$ were fixed $\mathrm{O} / \mathrm{N}$ in $2 \%$ (wt/vol) paraformaldehyde (TAAB Lab) and $2.5 \%$ (vol/vol) glutaraldehyde (Merck) in $0.1 \mathrm{MPB}$ (Sigma-Aldrich, Steinheim, Germany), postfixed for $2 \mathrm{~h}$ with $1 \%$ (wt/vol) osmium tetroxide (TAAB Lab) containing $0.8 \%$ (wt/vol) potassium hexocyanoferrate (Sigma-Aldrich) in PB, sequentially dehydrated in acetone, embedded in Eponate 12 resin (Ted Pella Inc.), and polymerized at $60^{\circ} \mathrm{C}$ for $48 \mathrm{~h}$. Ultrathin sections $(70 \mathrm{~nm})$ of selected areas obtained with Leica ultracut UCT microtome (Leica Microsystems, Mannheim, Germany) were placed on 200-mesh carbon-coated copper grids and contrasted with conventional uranyl acetate and lead citrate solutions. Ultrathin sections were then observed in a TEM Jeol JEM-1400 (Jeol Ltd., Tokyo, Japan) operating at $80 \mathrm{kV}$ and equipped with a CCD

Table 2. Sequence, annealing temperature (At), concentration ( $\mu M$ ), and amplicon size (bp) of forward and reverse primers used for quantitative PCR and accession number or reference

\begin{tabular}{|c|c|c|c|c|c|}
\hline Gene & Forward primer & Reverse primer & At, ${ }^{\circ} \mathrm{C}$ & $\mu M$ & $\begin{array}{l}\text { Accession no. } \\
\text { or reference }\end{array}$ \\
\hline GAPDH & GCATCGTGGAGGGACTTATGA & GGGCCATCCACAGTCTTCTG & 52 & 0.125 & NM_001034034 \\
\hline
\end{tabular}


Gatan (Gatan Inc., Pleasanton, CA) ES1000W Erlangshen camera.

A semiquantitative analysis was performed on $10 \mathrm{ul}-$ trathin sections randomly chosen from 3 different areas per treatment. The parameters studied were presence of mucus on the cell surface, mitochondrial damage, and cell death (necrosis or apoptosis). For each treatment, a value following a scale from healthy, without alteration $(-)$ to high alteration $(+++)$ was assigned for each parameter. Briefly, mucus was observed as a electrodense layer coating surface cells; edematous mitochondria was considered when the organelles showed higher size, round shape, nonhomogeneous matrix electrodensity, and/or disorganized or disappeared cristae; necrotic cells showed nonhomogeneous and disorganized cytosol and conserved nucleus (see representative images in Figure 8).

\section{Statistical Analyses}

Before statistical analyses, data were transformed by log or square root when necessary to achieve a normal distribution. Results herein are expressed as means of nontransformed data \pm SEM obtained with normalized data (unless otherwise stated). Data were analyzed using a mixed-effects model (SAS Inst. Inc., Cary, NC), considering treatment and infection as fixed effects and animal (the donor for the cell cultures) as a random effect. Data from TEM were analyzed using a Fisher exact test (SAS Inst. Inc.), assigning a value from 0 $(-)$ to $3(+++)$ for each parameter. Differences were considered significant when $P<0.05$.

\section{RESULTS}

\section{Selection of LAB Combination In Vitro}

The best combination of LAB strains tested in our previous work (Genís et al., 2016) was selected in vitro taking into account its ability to reduce inflammation and $E$. coli infection.

Escherichia coli Infection. The effect of the LAB combinations on E. coli infection is presented in Figure 1A. The E. coli count was reduced by $95.1 \%$ ( $P$ $<0.0001$ ) when using LAB combination D (Table 1; $L$. rhamnosus ratio $25, P$. acidilactici ratio 25 , and $L$. reuteri ratio 2$)$; whereas, it was increased $(P<0.0001)$ with LAB combinations $\mathrm{A}$ and $\mathrm{B}(56.0$ and $75.6 \%$, respectively) relative to culture with $E$. coli inoculum alone. No differences were found with LAB combination C. Furthermore, LAB combination D was able to surpass $P$. acidilactici, used as positive control, which reduced $E$. coli infection by $89.7 \%$.

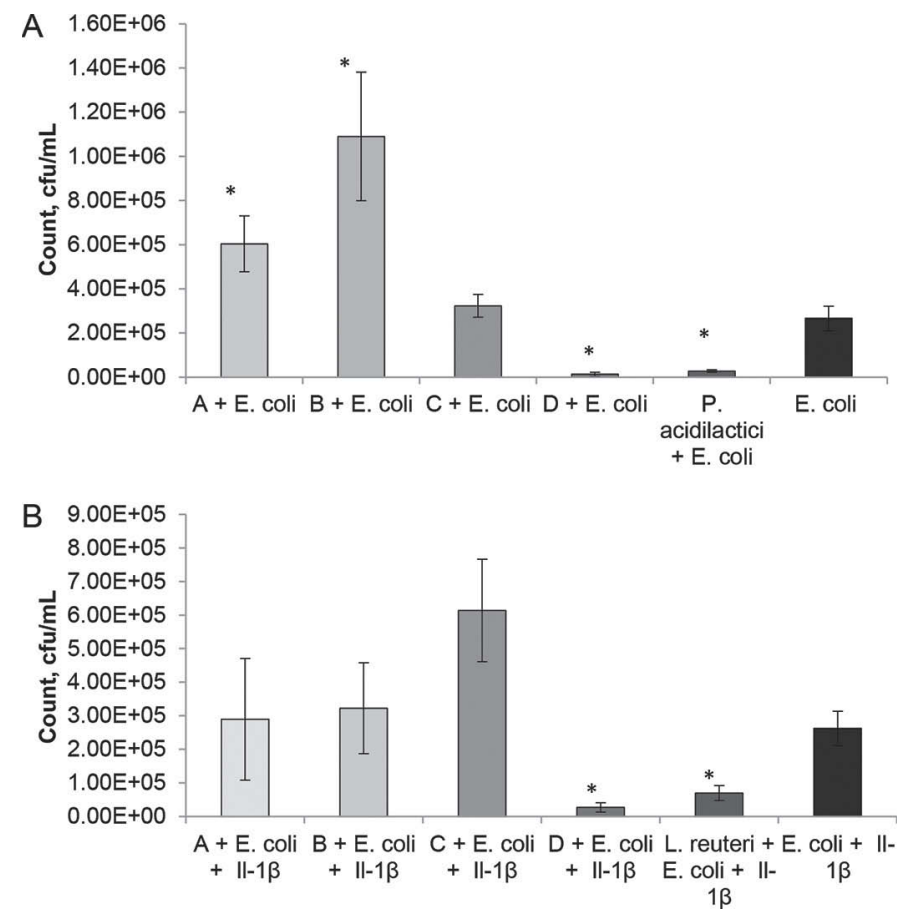

Figure 1. Escherichia coli infection of primary endometrium cultures. Viable cell counts $(\mathrm{cfu} / \mathrm{mL})$ of $E$. coli for each combination of lactic acid bacteria (explained in Table 1) in an endometrium in the absence (A) or in the presence of a basal inflammation (B). Bars represent means \pm SE. Bars with an asterisk differ $(P<0.01)$ from $E$. coli. $P$. acidilactici $=$ Pediococcus acidilactici; $L$. reuteri $=$ Lactobacillus reuteri.

The probiotic potential and modulatory effects of the LAB combinations against endometrial E. coli infection were similar in the presence (Figure $1 \mathrm{~A}$ ) or absence of a basal inflammation (Figure 1B). Under basal inflammation, E. coli infection was reduced with LAB combination $\mathrm{D}(89.78 \% ; P<0.01)$, and no differences were found with other LAB combinations. Lactic acid bacteria combination $\mathrm{D}$ was also able to surpass the decrease of infection induced by $L$. reuteri alone (73.5\%), which was used as a positive control to reduce infection under basal inflammation.

Innate Immunity Under Acute Inflammation. The expression of $C X C L 8$ and $I L 1 B$ genes was used as markers of innate immunity under acute inflammation caused by E. coli treatment of either LAB-treated or nontreated endometrial cells. The abundance of $C X C L 8$ mRNA was affected $(P<0.01)$ by LAB treatment when cells were not infected (Figure 2A, open bars) and also $(P<0.0001)$ in the presence of infection (Figure $2 \mathrm{~A}$, gray bars). Specifically, when cells were treated with the LAB combinations $\mathrm{C}$ and D, 1.7- and 2.1-fold increments in $C X C L 8$ expression in epithelial cells were observed, respectively, compared to nontreated cells 
(negative control). No differences were observed when LAB combinations A and B were applied to epithelial primary cultures of endometrium.

The expression of the CXCL8 gene increased 21.8fold with respect to the negative control (Figure 2A, gray bars), but it was down-regulated when $E$. coli was applied with LAB combinations A, B, C, or D (11.8-, $2.0-, 4.7-$, and 4.7-fold reduction, respectively; Figure $2 \mathrm{~A}$, gray bars).

The gene expression of $I L 1 B$ was affected by $\mathrm{LAB}$ treatment $(P<0.0001)$ when cells were uninfected (Figure $2 \mathrm{~B}$, open bars) and also $(P<0.0001)$ in the presence of infection (Figure 2B, gray bars). Cells treated with $\mathrm{LAB}$ combinations $\mathrm{A}$ and $\mathrm{C}$ expressed more $I L 1 B$ than the negative control (13.9- and 21.7fold, respectively). No differences were found with the other LAB combinations (Figure 2B, open bars).

The mRNA abundance of $I L 1 B$ in the endometrium infected with $E$. coli increased 137.5-fold with respect to the negative control. However, this increment was reduced when cells were treated with either LAB combination (5.5-, 3.1-, 10.6-, and 2.2-fold, for A, B, C, and D, respectively; Figure 2B, open bars).

Innate Immunity Under Basal and Acute Inflammation. The gene expression of CXCL8 in the basal tissue inflammation model of endometrial cells (cells pretreated with $10 \mu \mathrm{g} / \mu \mathrm{L}$ of IL-1 $\beta$ ) was affected by the different LAB combinations both in the presence $(P<0.0001$; Figure 3A, gray bars $)$ and in the absence of an acute inflammation caused by $E$. coli infection $(P$ $<0.0001$; Figure 3A, open bars). Pretreatment of the endometrium with IL-1 $\beta$ increased the expression of CXCL 8 gene by 6.2 -fold, but it only increased 1.4 -fold when the basal inflammation was induced in the presence of LAB combination B (Figure 3A, open bars).

Infection with $E$. coli increased 2.35-fold the expression of CXCL8 by epithelium under a basal inflammation. When cells were treated with $\mathrm{LAB}$ combinations $\mathrm{A}$ or $\mathrm{C}$, a decreased expression of $C X C L 8$ was observed (2.6- and 2.2-fold, respectively), whereas, the LAB combination D only tended $(P=0.08)$ to decrease $C X C L 8$ expression, and no differences were found with the LAB combination B (Figure $3 \mathrm{~B}$ ).

The mRNA abundance of $I L 1 B$ in the endometrium in the presence of basal inflammation was affected by LAB combination when acute inflammation was induced (Figure 3B, gray bars; $P<0.0001$ ). The inflamed endometrium expressed 49 -fold more IL1B than the negative control. However, no differences were observed when the LAB treatments were applied (Figure 3B, open bars). Escherichia coli infection (acute inflammation) raised the expression of $I L 1 B$ 1.93-fold compared to uninfected cells under basal inflammation When the
LAB combinations were applied, a reduction (relative to negative control) was observed in all cases: 2.1-fold for $\mathrm{LAB}$ combination A, 1.7-fold for LAB combination B, 2.3-fold for LAB combination C, and 1.9-fold for LAB combination D (Figure 3B, gray bars).
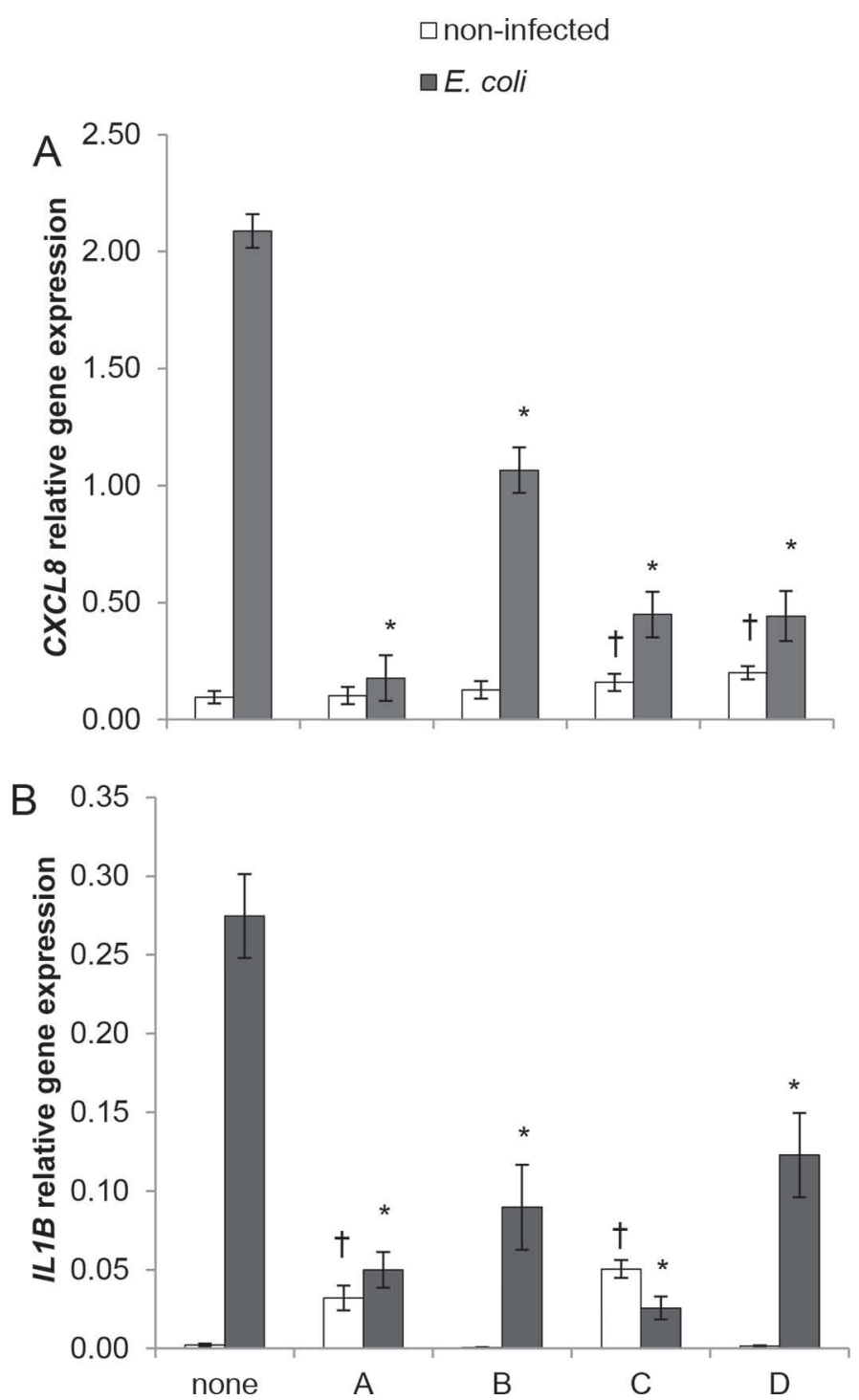

Figure 2. Innate immune response in primary endometrial cultures under an acute inflammation. The y-axis represents the arithmetic mean fold change relative to expression of a reference gene $(G A P D H)$. (A) Relative expression of $C X C L 8$ when cells were treated with lactic acid bacteria (LAB) combinations in the absence (open bars) or in the presence of an Escherichia coli infection (gray bars). (B) Gene expression of $I L 1 B$ in uninfected (open bars) and infected (gray bars) cells. Bars represent means \pm SEM (A) or SE (B) for the different treatments. †Bars differ $(P<0.01)$ from the negative control; *bars differ $(P<0.01)$ from $E$. coli control. Negative control and E. coli control differed at $P<0.0001$. 


\section{LAB Combination for Ex Vivo Experiments}

The LAB combination selected to conduct the ex vivo experiments was the combination $\mathrm{D}$ (L. rhamnosus ratio $25, P$. acidilactici ratio 25 , and $L$. reuteri ratio 2 ).

Ex Vivo Acute Inflammation Model. The secretion of IL-8, IL-1 $\beta$, and IL-6 was evaluated after an acute inflammation produced by $E$. coli infection of either LAB-treated or nontreated explants.

Interleukin- 8 secretion was affected $(P<0.0001)$ by E. coli infection, and an interaction $(P<0.0001)$ between infection and treatment was also observed (Figure $4 \mathrm{~A})$. When the probiotic combination was applied to explants, IL-8 secretion increased 1.6-fold compared to the negative control. When infection was induced, the secretion of IL-8 increased 3.7-fold compared to the negative control. However, in the presence of the probiotic combination the secretion of IL- 8 decreased by 2.20 -fold. No differences were found in the secretion of IL- 8 between the explants treated with probiotic in the presence or absence of an $E$. coli infection.

The secretion of IL-1 $\beta$ was affected by LAB treatment $(P<0.0001)$, infection $(P<0.0001)$, and the interaction between treatment and infection $(P<0.0001$, Figure 4B). The probiotic combination increased the secretion of IL-1 $\beta$ by 2.1-fold compared to the negative control. When the explants were infected with $E$. coli, the secretion of IL-1 $\beta$ increased 6.3 -fold, but the increase was lesser when the infection of $E$. coli was induced in cells treated with LAB (2.5-fold). Hence, the probiotic combination was able to reduce by 1.2 -fold the final secretion of IL-1 $\beta$ in the presence of an E. coli infection.

The secretion of IL-6 was affected by infection $(P$ $<0.0001$ ) and the interaction between infection and treatment $(P<0.0001$, Figure $4 \mathrm{C})$. The probiotic combination increased the secretion of IL-6 1.8-fold compared to the negative control. When the explants were infected by $E$. coli, secretion of IL-6 increased 4.5fold, whereas when explants were pretreated with the probiotics, IL-6 secretion decreased 2.2-fold.

Ex Vivo Total Inflammation Model. The secretion of IL-8, IL-1 3 , and IL-6 was evaluated in LABtreated and untreated endometrial explants after inducing inflammation (basal + acute inflammation).

The secretion of IL- 8 was affected by treatment $(P$ $<0.0001)$, infection $(P<0.0001)$, and the interaction between treatment and infection $(P<0.0001$, Figure 5A). Escherichia coli infection increased the secretion of IL-8 1.8-fold compared to the negative control. When the LAB treatment was previously applied, secretion of IL-8 decreased 1.6-fold. No differences were observed between the negative control and explants pretreated with LAB. $\square$ non-infected

$\square$ E. coli
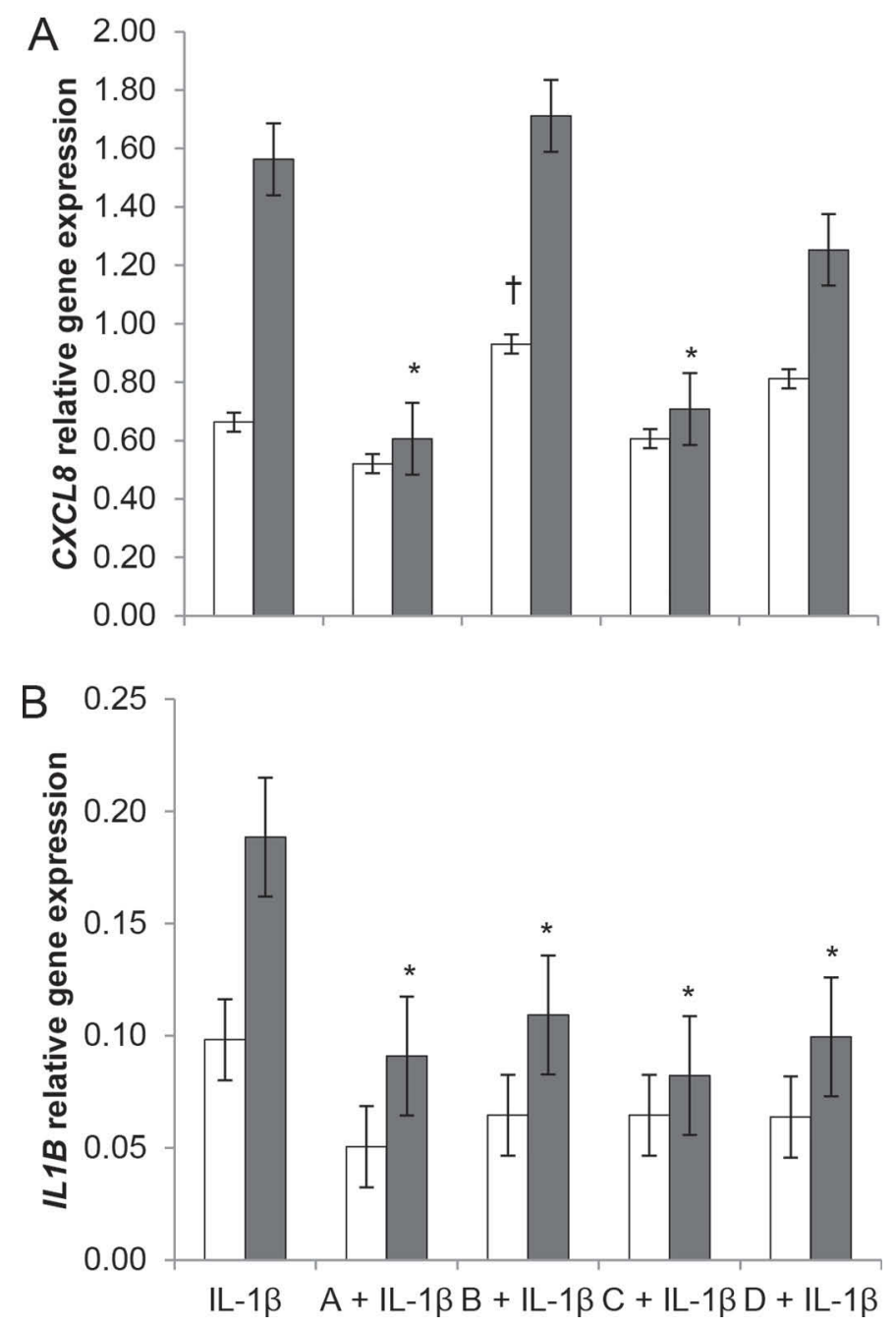

Figure 3. Innate immune response of primary endometrial cultures under a total (acute and basal) inflammation. The y-axis represents the arithmetic mean fold change relative to an expression of a reference gene $(G A P D H)$. (A) Expression of $C X C L 8$ gene when cells were treated with lactic acid bacteria (LAB) combinations in the absence (open bar) or in the presence of an Escherichia coli infection (gray bars). (B) Gene expression of $I L 1 B$ in infected (gray bars) and uninfected (open bars) cells. Bars represent means \pm SEM for the different treatments. †Bars differ $(P<0.05)$ from IL-13; *bars differ $(P<0.05)$ from E. coli + IL-1 $\beta$. Negative control and E. coli control differed at $P<0.0001$.

Secretion of IL-1 $\beta$ was affected by infection $(P<$ $0.0001)$ and the interaction between treatment and infection $(P<0.0005$, Figure 5B). Escherichia coli infection increased the secretion of IL-1 $\beta$ 1.1-fold compared to the negative control. When the noninfected explants were treated with LAB, an increment of 1.04-fold was observed compared to the negative control and no differences were perceived in comparison with the infected 
explants. The combination of the LAB and E. coli increased the secretion of IL-1 $\beta$ 1.1-fold compared with the infected explants.
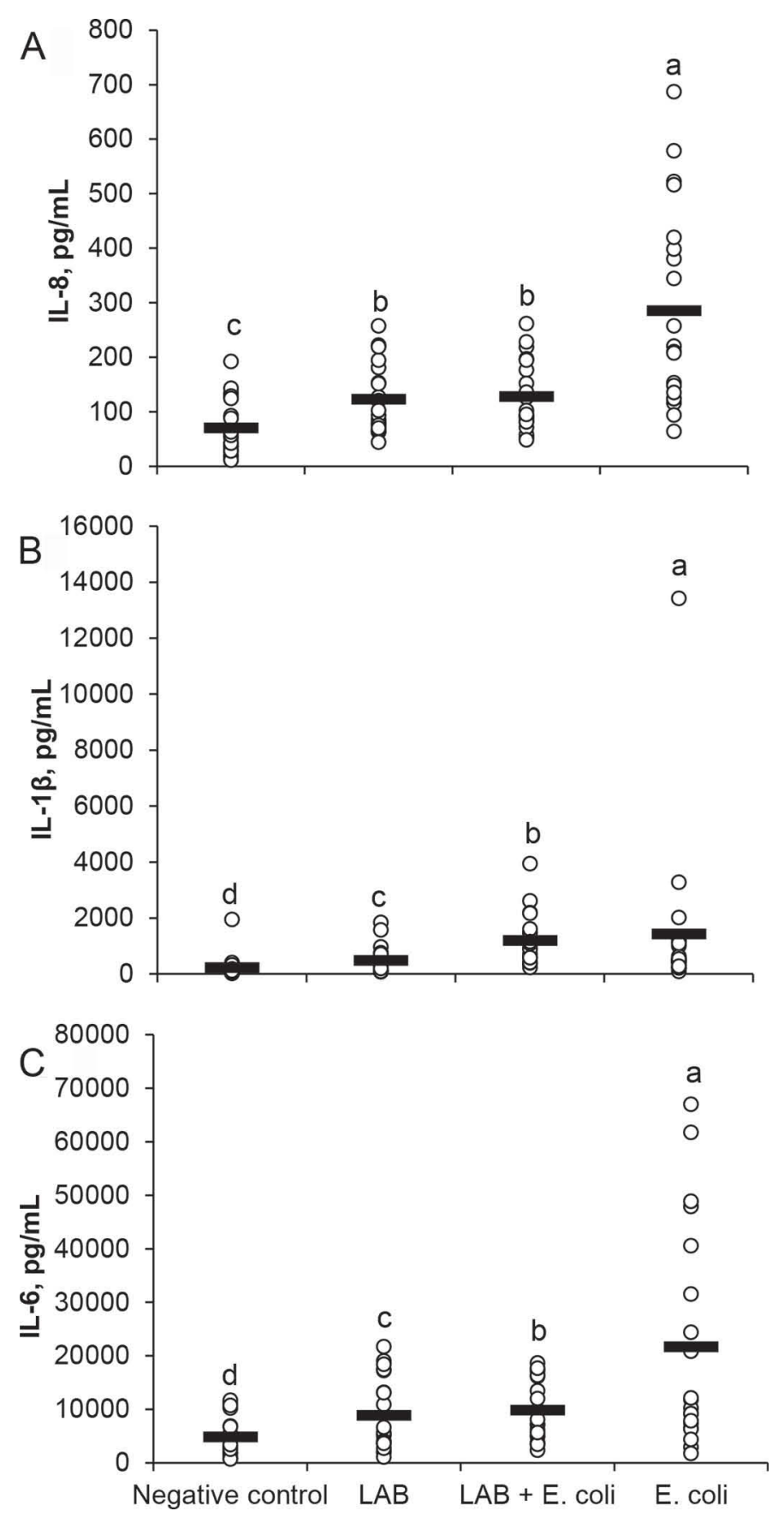

Figure 4. Innate immune response in endometrial explants treated ex vivo under an acute inflammation. Secretion $(\mathrm{pg} / \mathrm{mL}$ ) of IL-8 (A), IL-1 $\beta$ (B), and IL-6 (C). Dots represent means for each treatment and cow, whereas lines represent the means for each treatment. Columns with different letters $(\mathrm{a}-\mathrm{d})$ differ $(P<0.0001) . \mathrm{LAB}=$ lactic acid bacteria; $E$. coli = Escherichia coli.
Secretion of IL-6 was affected by infection $(P<$ $0.0001)$ and the interaction between treatment and infection $(P<0.0002$, Figure 5C). The LAB treatment increased the secretion of IL-6 1.1-fold compared to the negative control. When the explants were infected with E. coli, the secretion of IL-6 increased 1.6-fold. Although $E$. coli induced the explants treated with probiotics to secrete more IL-6 than those not infected (1.2-fold), the probiotic combination resulted in 1.2 -fold reduction of the secretion of IL- 6 .
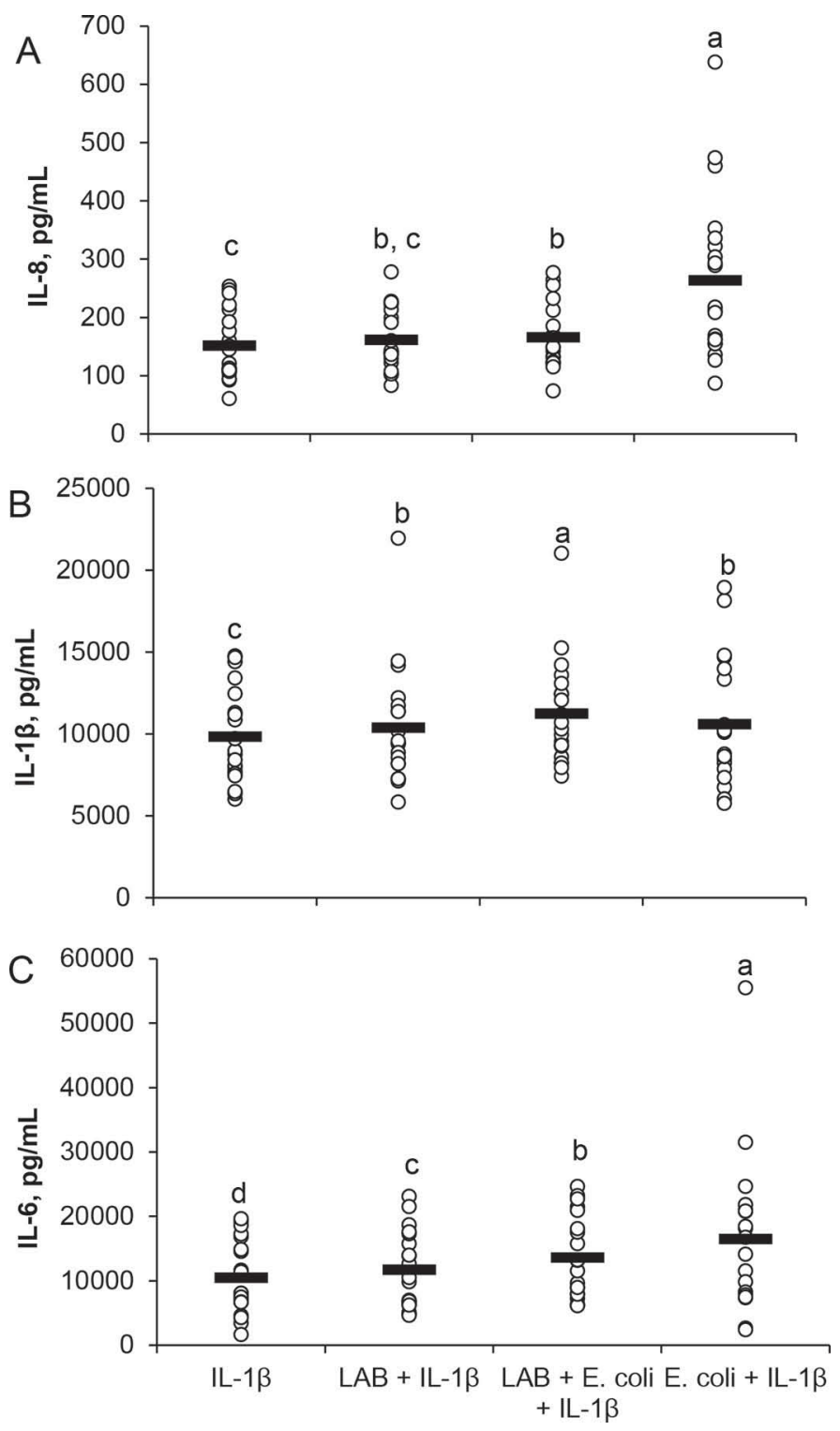

Figure 5. Innate immune response in endometrial explants treated ex vivo under a total inflammation (basal plus acute). Secretion (pg/ $\mathrm{mL}$ ) of IL-8 (A), IL-1 $\beta$ (B), and IL-6 (C). Dots represent means for each treatment and cow, whereas lines are the means for each treatment. Columns with different letters $(\mathrm{a}-\mathrm{d})$ differ $(P<0.0001) . \mathrm{LAB}=$ lactic acid bacteria; $E$. coli = Escherichia coli. 


\section{Field Emission Scanning Electron Microscopy}

The study of LAB by FESEM showed bacteria with similar size and shape in each culture and also after incubation with primary endometrial epithelia (Figure 6A, 6B). Moreover, E. coli bacteria were also observed in contact with epithelial cells either incubated alone or with the LAB combination D (Figure 6C, 6D). Escherichia coli alone or E. coli and LAB appeared in low numbers in the surface of the epithelial cells and in no case formed biofilms or interactions between each other (Figure 6C, 6D). The abundance of E. coli was lower in samples treated with LAB than in those infected with E. coli alone $(P<0.05)$.

A qualitative assessment of epithelial cells was performed by FESEM, and a healthy epithelium was observed in all treatments (epithelial cells with normal size and shape and normal appearance of microvilli), but in cultures infected with E. coli, abundant areas with cell debris and bacilli were observed on the surface of epithelial cells (Figure 7). These areas of damaged epithelial cells were less abundant in the control and in the LAB pre-incubated cells than in cells infected with E. coli.

\section{Transmission Electron Microscopy}

Quantitative data by TEM clearly illustrated the highest incidence of necrosis among all samples infected with $E$. coli, indicating an obvious harmful effect of this pathogen in our model $(P=0.07$, Figure 8$)$. In contrast, cell death decreased with the use of LAB probiotics. A similar pattern between treatments was found for mitochondrial damage (edematous mitochondria; $P<$ 0.01). No morphological signs of apoptosis were found in any of the treatments.

\section{DISCUSSION}

Understanding the mechanisms of infection and immunity normally involves the use of in vitro studies. However, the generation of cell cultures usually disrupts the tissue architecture and the spatial arrangement of cells, which are often necessary for normal function (Vogel and Sheetz, 2006; Healy et al., 2014). The use of tissue explants provides the opportunity to study the overall inflammatory response to pathogens depending on the sum of actions of multiple cell types rather than just epithelial or specialized immune cells. In this study, endometrial tissue from nonpregnant cows collected in the slaughterhouse was used to make explants. It is important to take into account that it is an experimental approach and the tissue does not come from actual postpartum cows. The LAB combinations tested herein were selected from the results obtained during previous experiments (Genís et al., 2016). Briefly, 3 doses of a combination of $4 \mathrm{LAB}$ were tested (L. rhamnosus, $P$. acidilactici, L. reuteri, and L. sakei) for their capacity to modulate basal inflammation in an endometrial primary culture infected with $E$. coli. The main results obtained in our previous work were that $P$. acidilactici ratio 25 ( 25 bacterial cells to 1 epithelial cell) was able to inhibit $E$. coli infection and down-regulate total inflammation; L. rhamnosus ratios 100 and 25 were able to reduce total inflammation but increased the extent of $E$. coli infection with the greatest dose; and $L$. reuteri ratio 2 was able to reduce $E$. coli infection in the presence of a basal inflammation (Genís et al., 2016).

Overall, all the biochemical and ultrastructural results herein demonstrated that the best LAB combination to fight $E$. coli infection in the endometrium was the LAB combination D composed of L. rhamnosus, $P$. acidilactici, and $L$. reuteri in a ratio of 25:25:2 (Figures 1 and 2). Lactobacillus reuteri played a key role in the $\mathrm{LAB}$ combination as indicated by the comparison of LAB combination $\mathrm{D}$ and $\mathrm{B}$, which differed only in the presence (D) or absence (B) of this bacterium. The presence of $L$. reuteri (D) reduced 21.6- and 83.8-fold the extent of $E$. coli infection compared with the levels achieved with the LAB combination $\mathrm{B}$ with or without a basal inflammation, respectively. Despite the importance of $L$. reuteri, the mixture with $L$. rhamnosus and $P$. acidilactici was necessary to improve the performance obtained with $L$. reuteri and $P$. acidilactici alone, which had previously been selected as the best LAB strains inhibiting infection with or without inflammation, respectively (Genís et al., 2016). These results confirmed our hypothesis that an adequate combination of probiotics would efficiently counteract an endometrial infection by $E$. coli. The LAB combination D not only most efficiently reduced the E. coli infection (Figure 1 ), but it also led to the greatest reduction of acute and basal inflammation (Figures 2 and 3). Probably, in the case of the combination D applied to epithelial cultures, the reduction of count (cfu) of E. coli (Figure 1) was the main cause behind the decreased expression of proinflammatory cytokines during the infection (Figure 2), because lower bacterial counts cause less acute inflammation.

The healthy uterus is able to efficiently clear bacterial infection, and once bacteria have gained access to the uterus, the most important component of uterine defense is nonspecific phagocytosis by neutrophils (LeBlanc, 2008). Parturition in dairy cattle is associated with impairment of polymorphonuclear leukocyte phagocytosis and with a decrease in the ability to fight bacterial infections (Kehrli et al., 1989). A decrease in neutrophils' activity during the periparturient pe- 


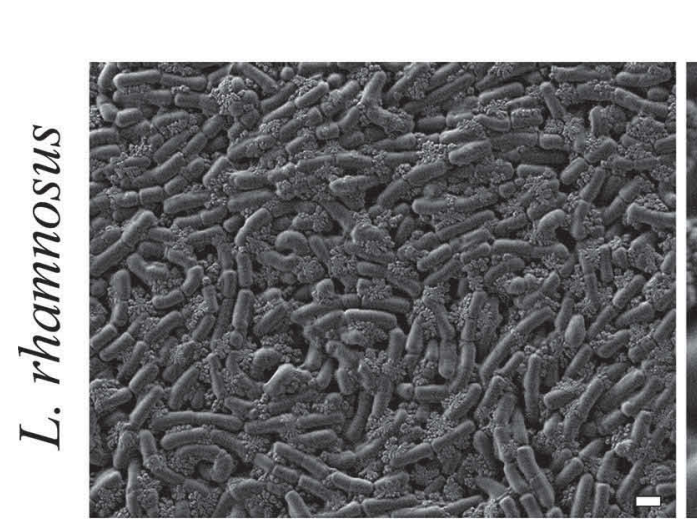

A
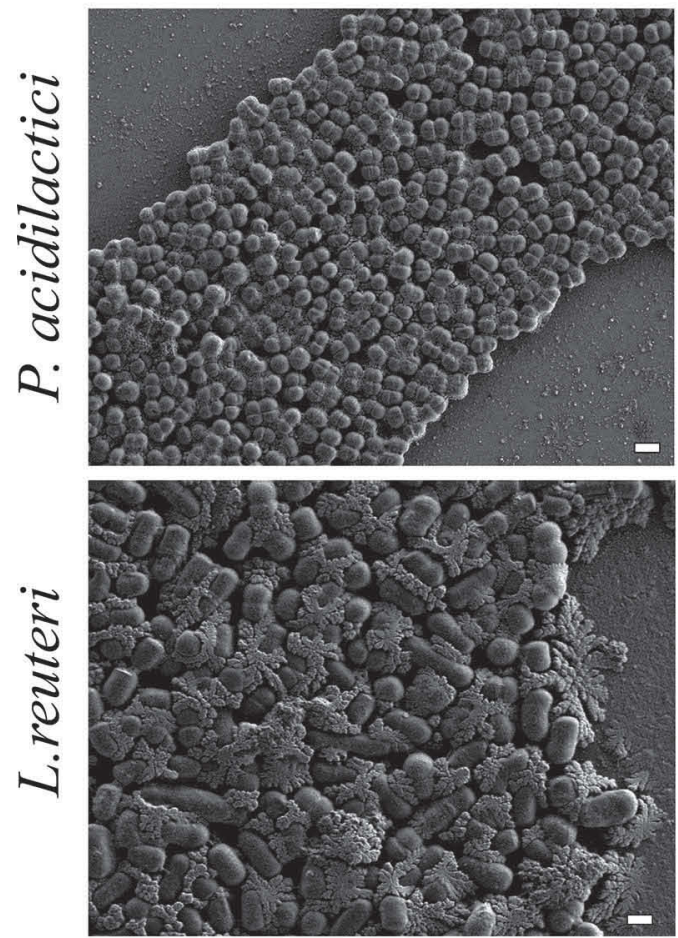

C

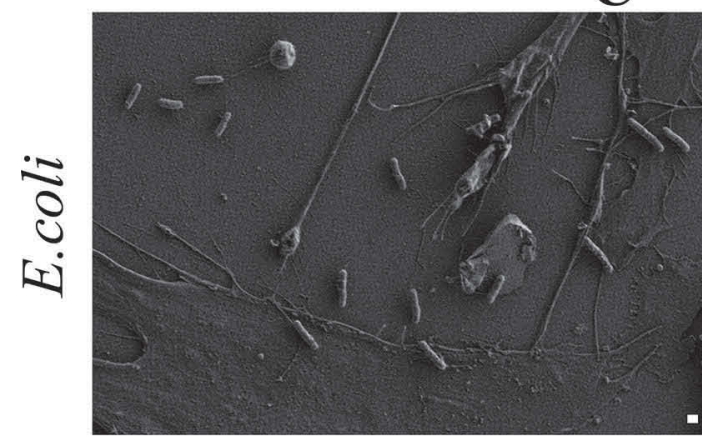

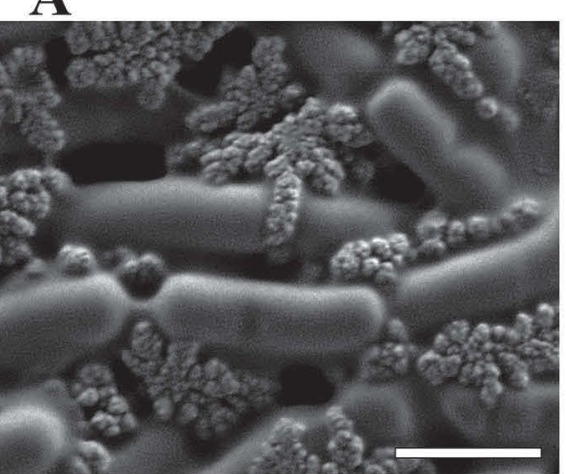
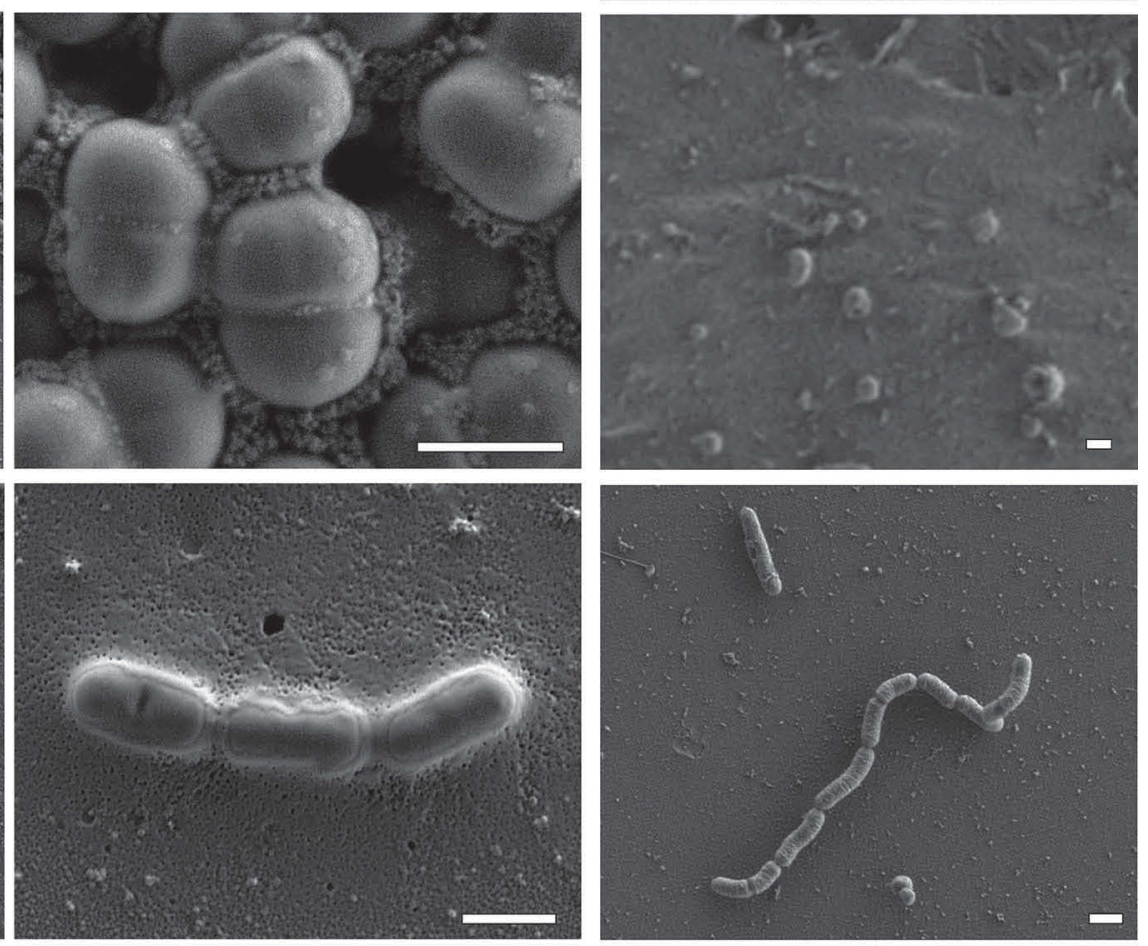

D
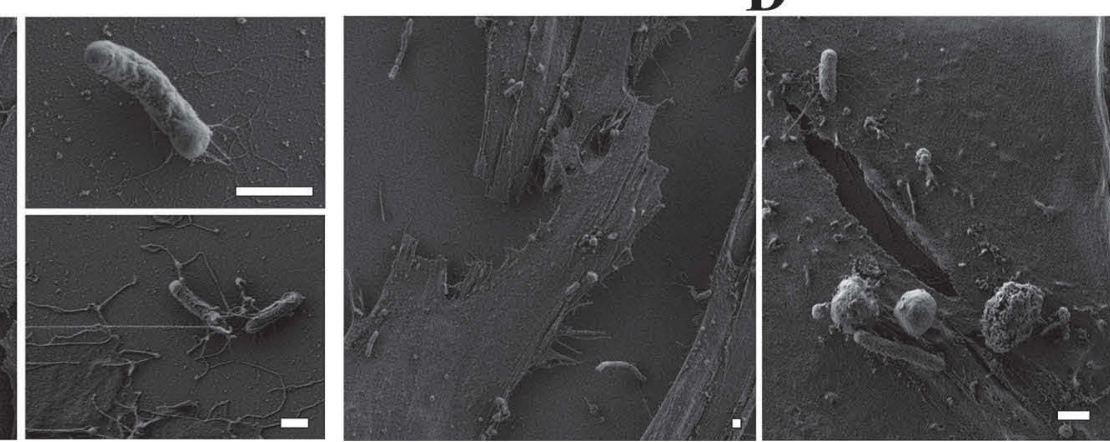

Figure 6. Representative images of lactic acid bacteria (LAB) and Escherichia coli. (A) General view and detail of LAB cultures. (B) Detail of LAB incubated with epithelial cells. General view and details of E. coli incubated (C) alone or (D) with LAB combination (Lactobacillus rhamnosus, Pediococcus acidilactici, Lactobacillus reuteri). Bar size: $1 \mu \mathrm{m}$. 
C-
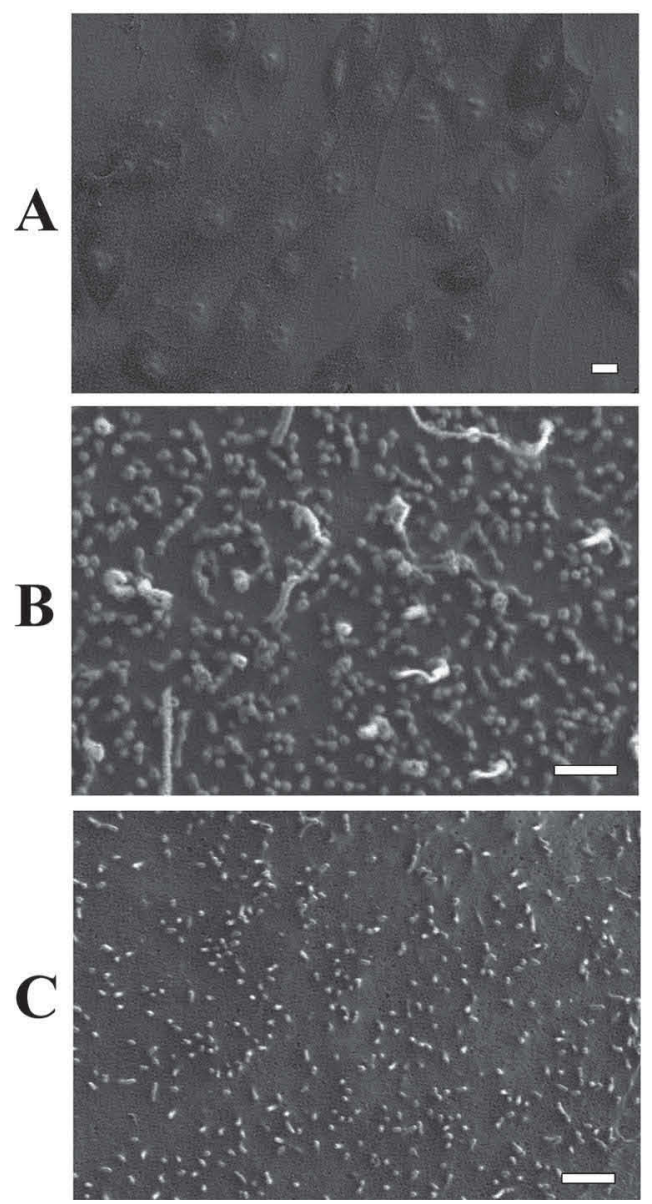

E. coli
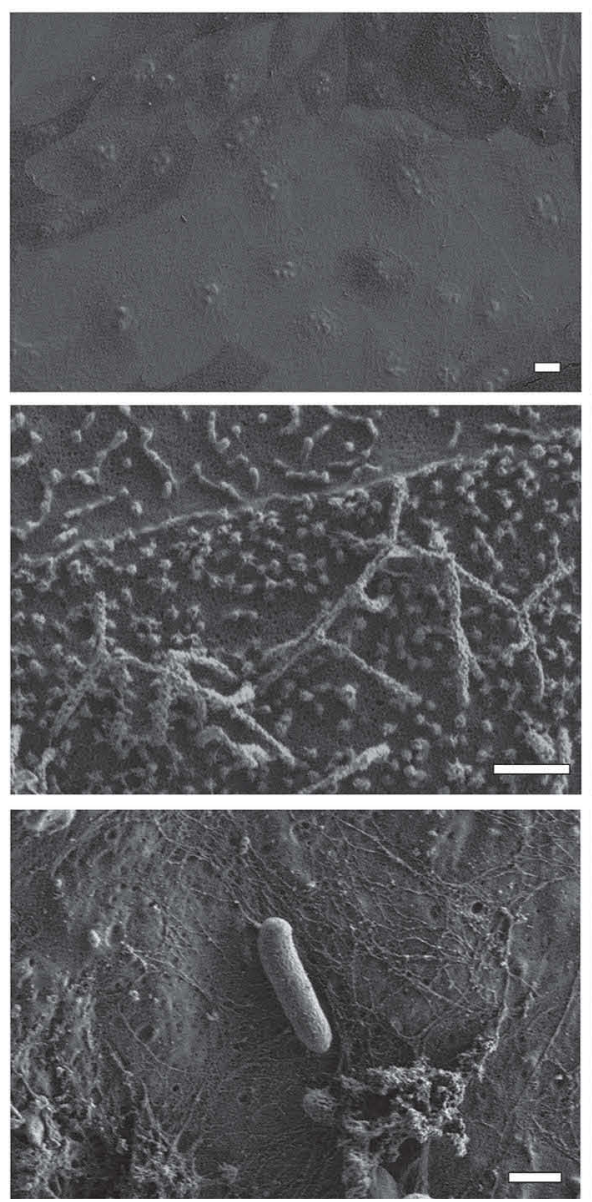

$\mathrm{LAB}+E_{\text {. coli }}$
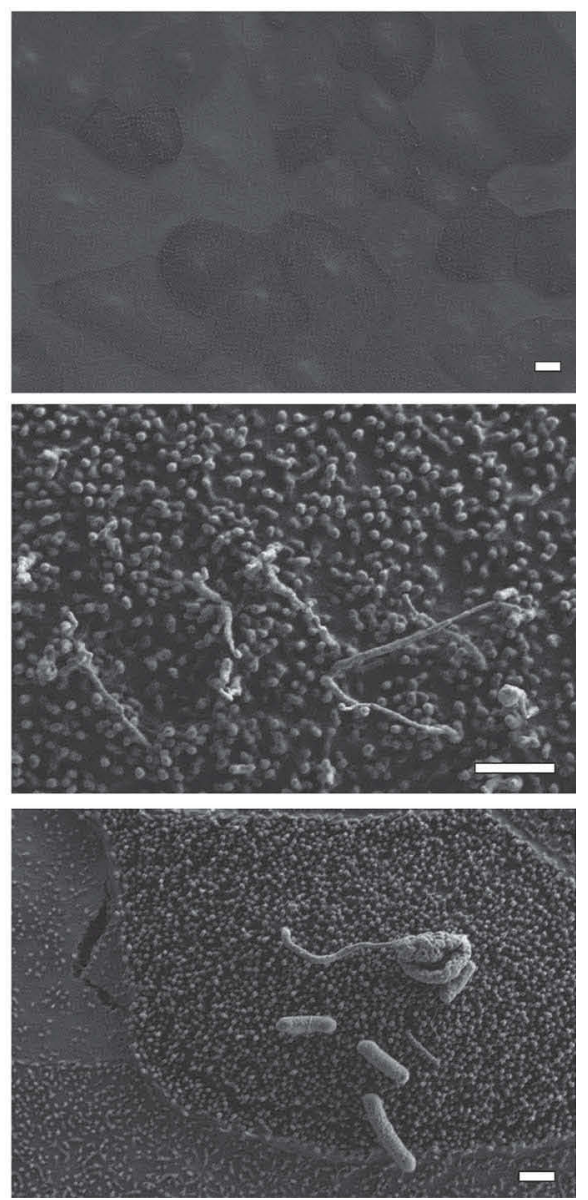

Figure 7. Representative images of epithelial cells of negative control (C-), Escherichia coli and lactic acid bacteria (LAB) with E. coli. (A) General view of epithelial cell surface showing similar aspect in the 3 treatments. (B) Detail of cell surface of the 3 treatments showing microvilli longer and more abundant in epithelia treated with E. coli alone and E. coli with LAB than with control cells. (C) Detail of E. coli bacilli (rodshape bacterium) with cells covered with cell debris (misshapen remnants of degraded organelles and other cell components) or detail of $E$. coli with LAB associated with cells with a normal appearance. Bar size for general view $=5 \mu \mathrm{m}$; for the rest $=1 \mu \mathrm{m}$.

riod has been suggested to influence the occurrence of uterine infections in both cows (Cai et al., 1994; Hammon et al., 2006) and buffalos (Patra et al., 2013). The phagocytic capacity of neutrophils remains high throughout the peripartum period, but their killing capacity is impaired (Hussain, 1992).

Several studies demonstrate the capacity of L. rhamnosus to activate neutrophils (Seow et al., 2010; Kandasamy et al., 2011). Fish receiving a feed supplemented with $P$. acidilactici also presented elevated proportions of circulating neutrophils (Standen et al., 2013), and L. reuteri recruited neutrophils against pneumovirus in mice (Garcia-Crespo et al., 2013).

Because IL- 8 is the main chemokine recruiting neutrophils, the increase in IL- 8 concentration observed when the LAB probiotic combinations were applied to the explants (Figures 4 and 5) could be responsible for the recruitment of neutrophils. This action, in combination with the previously demonstrated ability of LAB to reduce $E$. coli cfu, would protect the tissue against $E$. coli infection and consequent acute inflammation (with or without basal inflammation). Hence, the inflammatory response was less pronounced in LAB-treated and infected explants than in the explants infected but not treated with LAB (Figures 4 and 5). The LAB probiotics likely prepared the tissue pre-infection to efficiently respond against pathogens and avoid a high inflammatory response that could be deleterious for the uterus.

The FESEM images (Figures 6 and 7) demonstrated that no direct interaction occurred between the different LAB strains or with $E$. coli or between bacteria and endometrial cells, and that no biofilms formed. The presence of LAB may have reduced through competition mechanisms the direct interaction of $E$. coli with 
the epithelial cells. The absence of biofilm formation or direct contact between $\mathrm{LAB}$ and $E$. coli suggests that the mode of action of LAB could be related to the presence of extracellular bioactive peptides and bacteriocins (important antimicrobial metabolites produced by LAB) (Hor and Liong, 2014). In this context, pediocin PA, a bacteriocin produced by $P$. acidilactici, has been described to inactivate Listeria and other food pathogens (Woraprayote et al., 2013). Also, a recent study showed that increased secretion of MUC3 mucin leads to reduced adhesion of enteropathogenic E. coli and enterohemorrhagic E. coli strains (Mack et al., 2003; Pan et al., 2013). The bacterial exopolysaccharide re- uteran, synthesized by L. reuteri, has also been shown to reduce enterotoxigenic $E$. coli colonization of piglet jejunal epithelial cells (Zhang et al., 2015). Further studies will be carried out to demonstrate the involvement of those factors in the LAB protection against $E$. coli infection of bovine endometrium.

Cytokines and necrosis reflect the progression of inflammation (Perdomo et al., 1994; Ajonuma et al., 2010). In general, the loss of epithelial cells increases the risk of infections, inflammation, and other deleterious effects in the tissues (Perdomo et al., 1994). LAB treatment reduced mitochondrial damage in $E$. coli-infected cells compared to E. coli-infected cells without LAB
A

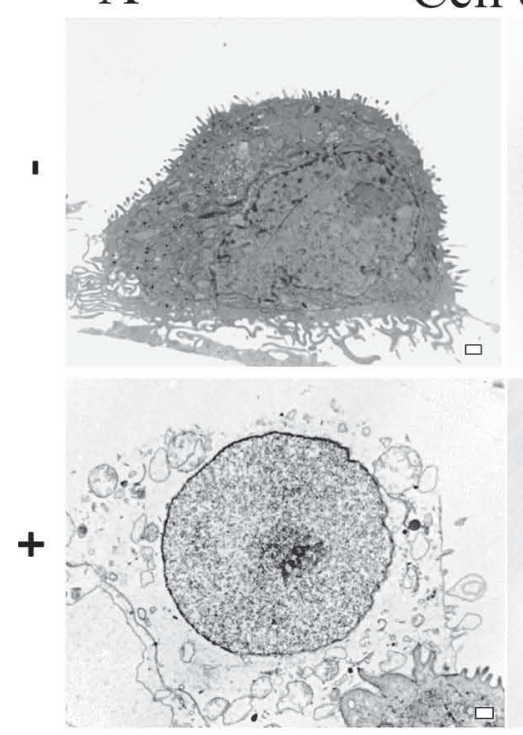

Cell death

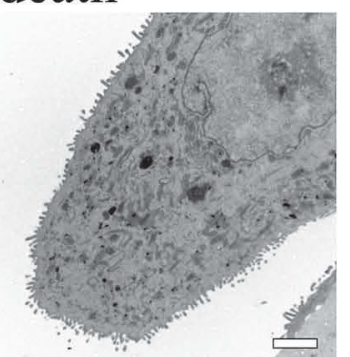

B
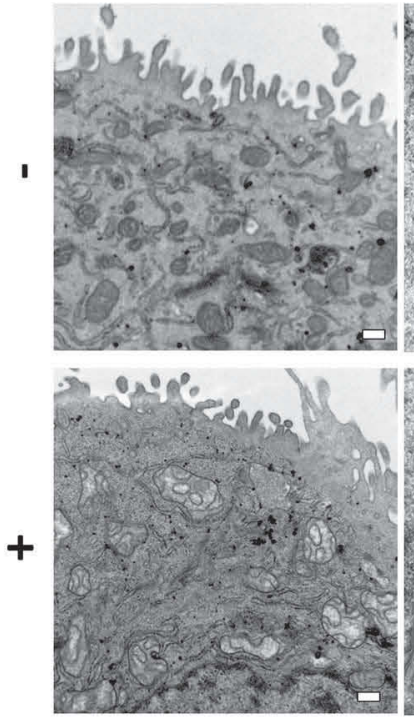

Mitochondrial damage
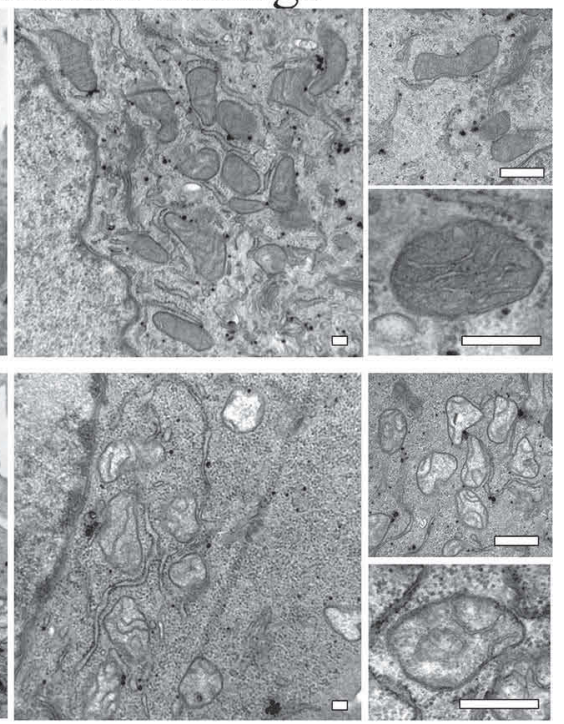

\section{Mucus on cell surface}
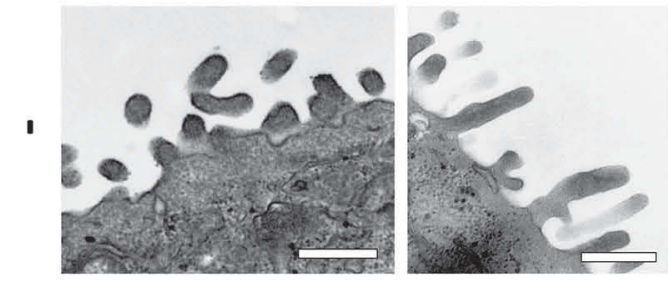

$\mathrm{D}$

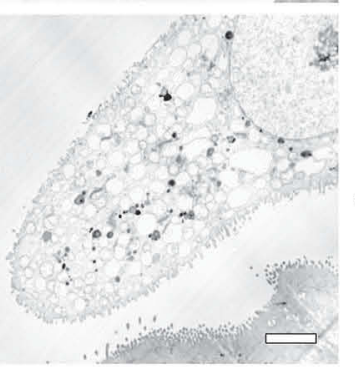

Treatment Cell death (Necrotic cells) Damaged mitochondria Mucus in cell surface

\begin{tabular}{cccc} 
C- & - & - & + \\
E. coli & +++ & +++ & - \\
LAB & - & + & + \\
\hline
\end{tabular}
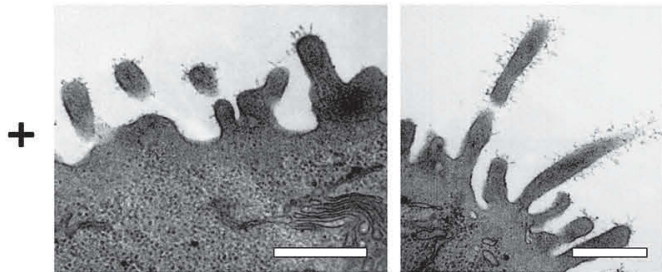

Figure 8. Representative images of semiquantitative assessment of ultrastructure of epithelial cells of negative control (C-), Escherichia coliinfected cells (E. coli), and cells treated with lactic acid bacteria and then infected with E. coli (LAB). (A) Healthy (-) and necrotic (+) cells. Bars size: $2 \mu \mathrm{m}$. (B) Healthy $(-)$ and damaged $(+)$ mitochondria. Bars size: $0.5 \mu \mathrm{m}$. (C) Absence $(-)$ or presence $(+)$ of mucus in cell surface. Bars size: $0.5 \mu \mathrm{m}$. (D) A semiquantitative assessment for all treatments ranging from no alteration $(-)$ to high alteration $(+++)$ was assigned for each parameter and treatment used for statistical comparisons. 
(Figure 8). Our ultrastructural findings are relevant because mitochondrial damage and cell death compromise the tridimensional organization of epithelial cells and hampers their barrier function, which is crucial for endometrium homeostasis (Bryant and Mostov, 2008). These results complemented our biochemical data because intracellular signaling pathways of inflammation actively participate in tissue homeostasis (Eritja et al., 2012) and may induce morphological changes (Saito et al., 2014).

\section{CONCLUSIONS}

A LAB combination consisting of $L$. rhamnosus, $P$. acidilactici, and $L$. reuteri in a ratio of 25:25:2 showed the best potential to modulate E. coli infection and endometrial inflammation in vitro compared with the individual LAB strains separately. Furthermore, the optimal LAB combination was able to reduce the secretion of inflammation markers (IL-8, IL-1 $\beta$, and IL-6) in the ex vivo acute inflammation model and in the ex vivo total inflammation model (IL-8 and IL-6). We also conclude that the physiological and morphological effects (namely proinflammatory cytokine production and necrosis) of the exposure of uterine cells to $E$. coli may be reduced in the presence of a combination of LAB. This ability to modulate and reduce or even neutralize the main pathological effects of $E$. coli infection demonstrates a promising potential of $\mathrm{LAB}$ probiotics as a therapeutic and preventive alternative against metritis in the periparturient cow.

\section{ACKNOWLEDGMENTS}

We are indebted to the Servei de Cultius i Producció d'Anticossos i Citometria and the Servei de Microscopia at the Autonomous University of Barcelona (Barcelona, Spain). The authors thank the Department of Ruminant Production of IRTA for helpful technical assistance and discussions. This study was funded by IRTA (Caldes de Montbui, Spain).

\section{REFERENCES}

Ajonuma, L. C., K. L. Fok, L. S. Ho, P. K. Chan, P. H. Chow, L. L. Tsang, C. H. Wong, J. Chen, S. Li, D. K. Rowlands, Y. W. Chung, and H. C. Chan. 2010. CFTR is required for cellular entry and internalization of Chlamydia trachomatis. Cell Biol. Int. 34:593-600.

Ametaj, B. N., S. Iqbal, F. Selami, J. F. Odhiambo, Y. Wang, M. G. Ganzle, S. M. Dunn, and Q. Zebeli. 2014. Intravaginal administration of lactic acid bacteria modulated the incidence of purulent vaginal discharges, plasma haptoglobin concentrations, and milk production in dairy cows. Res. Vet. Sci. 96:365-370.

Arnold, R., B. König, H. Werchau, and W. König. 2004. Respiratory syncytial virus deficient in soluble $\mathrm{G}$ protein induced an increased proinflammatory response in human lung epithelial cells. Virology 330:384-397.
Borges, A. M., G. D. Healey, and I. M. Sheldon. 2012. Explants of intact endometrium to model bovine innate immunity and inflammation ex vivo. Am. J. Reprod. Immunol. 67:526-539.

Borsberry, S., and H. Dobson. 1989. Periparturient diseases and their effect on reproductive performance in five dairy herds. Vet. Rec. 124:217-219.

Bryant, D. M., and K. E. Mostov. 2008. From cells to organs: Building polarized tissue. Nat. Rev. Mol. Cell Biol. 9:887-901.

Cai, T. Q., P. G. Weston, L. A. Lund, B. Brodie, D. J. McKenna, and W. C. Wagner. 1994. Association between neutrophil functions and periparturient disorders in cows. Am. J. Vet. Res. 55:934-943.

Deng, Q., J. F. Odhiambo, U. Farooq, T. Lam, S. M. Dunn, and B. N. Ametaj. 2015. Intravaginal lactic acid bacteria modulated local and systemic immune responses and lowered the incidence of uterine infections in periparturient dairy cows. PLoS One 10:e0124167.

Domènech, A., S. Parés, A. Bach, and A. Arís. 2014. Mammary serum amyloid A3 activates involution of the mammary gland in dairy cows. J. Dairy Sci. 97:7595-7605. http://dx.doi.org/http://dx.doi. org/10.3168/jds.2014-8403.

Drillich, M., O. Beetz, A. Pfutzner, M. Sabin, H. J. Sabin, P. Kutzer, H. Nattermann, and W. Heuwieser. 2001. Evaluation of a systemic antibiotic treatment of toxic puerperal metritis in dairy cows. J. Dairy Sci. 84:2010-2017.

Eritja, N., C. Mirantes, D. Llobet, G. Masip, X. Matias-Guiu, and X. Dolcet. 2012. ERalpha-mediated repression of pro-inflammatory cytokine expression by glucocorticoids reveals a crucial role for TNFalpha and IL1alpha in lumen formation and maintenance. J. Cell Sci. 125:1929-1944.

Galvão, K. N. 2011. Identifying and treating uterine disease in dairy cows. Pages 21-28 in Proc. 47th Florida Dairy Production Conf., Gainesville. Accessed Oct. 25, 2016. http://dairy.ifas.ufl.edu/ dpc/2011/Galvao.pdf.

Galvão, K. N., N. R. Santos, J. S. Galvão, and R. O. Gilbert. 2011. Association between endometritis and endometrial cytokine expression in postpartum Holstein cows. Theriogenology 76:290-299.

Garcia-Crespo, K. E., C. C. Chan, S. J. Gabryszewski, C. M. Percopo, P. Rigaux, K. D. Dyer, J. B. Domachowske, and H. F. Rosenberg. 2013. Lactobacillus priming of the respiratory tract: Heterologous immunity and protection against lethal pneumovirus infection. Antiviral Res. 97:270-279.

Genís, S., À. Bach, F. Fabregas, and A. Aris. 2016. Potential of lactic acid bacteria at regulating Escherichia coli infection and inflammation of bovine endometrium. Theriogenology 85:625-637.

Gilbert, R. O., and W. S. Schwark. 1992. Pharmacologic considerations in the management of peripartum conditions in the cow. Vet. Clin. North Am. Food Anim. Pract. 8:29-56.

Hammon, D. S., I. M. Evjen, T. R. Dhiman, J. P. Goff, and J. L. Walters. 2006. Neutrophil function and energy status in Holstein cows with uterine health disorders. Vet. Immunol. Immunopathol. 113:21-29.

Healy, L. L., J. G. Cronin, and I. M. Sheldon. 2014. Endometrial cells sense and react to tissue damage during infection of the bovine endometrium via interleukin 1. Sci. Rep. 4:7060.

Herath, S., D. P. Fischer, D. Werling, E. J. Williams, S. T. Lilly, H. Dobson, C. E. Bryant, and I. M. Sheldon. 2006. Expression and function of Toll-like receptor 4 in the endometrial cells of the uterus. Endocrinology 147:562-570.

Hor, Y. Y., and M. T. Liong. 2014. Use of extracellular extracts of lactic acid bacteria and bifidobacteria for the inhibition of dermatological pathogen Staphylococcus aureus. Zhonghua Pifuke Yixue Zazhi 32:141-147.

Hussain, A. M. 1992. Phagocytosis by uterine fluid and blood neutrophils and hematological changes in postpartum cows following normal and abnormal parturition. Theriogenology 37:1253-1267.

Kandasamy, M., B. H. Bay, Y. K. Lee, and R. Mahendran. 2011. Lactobacilli secreting a tumor antigen and IL15 activates neutrophils and dendritic cells and generates cytotoxic $\mathrm{T}$ lymphocytes against cancer cells. Cell. Immunol. 271:89-96.

Kehrli, M. E. Jr., B. J. Nonnecke, and J. A. Roth. 1989. Alterations in bovine neutrophil function during the periparturient period. Am. J. Vet. Res. 50:207-214. 
LeBlanc, S. J. 2008. Postpartum uterine disease and dairy herd reproductive performance: A review. Vet. J. 176:102-114.

LeBlanc, S. J. 2014. Reproductive tract inflammatory disease in postpartum dairy cows. Animal 8(Suppl 1):54-63.

Lincke, A., M. Drillich, and W. Heuwieser. 2007. Subclinical endometritis in dairy cattle and its effect on fertility - A review of recent publications [in German]. Berl. Munch. Tierarztl. Wochenschr. 120:245-250.

Mack, D. R., S. Ahrne, L. Hyde, S. Wei, and M. A. Hollingsworth 2003. Extracellular MUC3 mucin secretion follows adherence of Lactobacillus strains to intestinal epithelial cells in vitro. Gut 52:827-833.

Markusfeld, O. 1987. Periparturient traits in seven high dairy herds. Incidence rates, association with parity, and interrelationships among traits. J. Dairy Sci. 70:158-166.

Opsomer, G., Y. T. Grohn, J. Hertl, M. Coryn, H. Deluyker, and A. de Kruif. 2000. Risk factors for post partum ovarian dysfunction in high producing dairy cows in Belgium: A field study. Theriogenology $53: 841-857$.

Otero, M. C., L. Morelli, and M. E. Nader-Macias. 2006. Probiotic properties of vaginal lactic acid bacteria to prevent metritis in cattle. Lett. Appl. Microbiol. 43:91-97.

Overton, M., and J. Fetrow. 2008. Economics of postpartum health. Dairy cattle reproduction council convention. Accessed Oct. 25 2016. http://www.agweb.com/assets/import/files/d10047\%20 overton\%20report.pdf.

Pan, Q., Y. Tian, X. Li, J. Ye, Y. Liu, L. Song, Y. Yang, R. Zhu, Y. He, L. Chen, W. Chen, X. Mao, Z. Peng, and R. Wang. 2013. Enhanced membrane-tethered mucin 3 (MUC3) expression by a tetrameric branched peptide with a conserved TFLK motif inhibits bacteria adherence. J. Biol. Chem. 288:5407-5416.

Patra, M. K., H. Kumar, and S. Nandi. 2013. Neutrophil functions and cytokines expression profile in buffaloes with impending postpartum reproductive disorders. Asian-australas. J. Anim. Sci. 26:1406-1415.

Perdomo, O. J., J. M. Cavaillon, M. Huerre, H. Ohayon, P. Gounon, and P. J. Sansonetti. 1994. Acute inflammation causes epithelial invasion and mucosal destruction in experimental shigellosis. J. Exp. Med. 180:1307-1319.

Pfaffl, M. W. 2001. A new mathematical model for relative quantification in real-time RT-PCR. Nucleic Acids Res. 29:e45.

Rinaldi, M., F. Ceciliani, C. Lecchi, P. Moroni, and D. D. Bannerman. 2008. Differential effects of alpha1-acid glycoprotein on bovine neutrophil respiratory burst activity and IL- 8 production. Vet. Immunol. Immunopathol. 126:199-210.

Saito, T., K. Yoshida, K. Matsumoto, K. Saeki, Y. Tanaka, S. M. Ong, N. Sasaki, R. Nishimura, and T. Nakagawa. 2014. Inflammatory cytokines induce a reduction in E-cadherin expression and morphological changes in MDCK cells. Res. Vet. Sci. 96:288-291.
Seow, S. W., S. Cai, J. N. Rahmat, B. H. Bay, Y. K. Lee, Y. H. Chan, and R. Mahendran. 2010. Lactobacillus rhamnosus GG induces tumor regression in mice bearing orthotopic bladder tumors. Cancer Sci. 101:751-758.

Sheldon, I. M., J. Cronin, L. Goetze, G. Donofrio, and H. J. Schuberth. 2009. Defining postpartum uterine disease and the mechanisms of infection and immunity in the female reproductive tract in cattle. Biol. Reprod. 81:1025-1032.

Sheldon, I. M., J. G. Cronin, G. D. Healey, C. Gabler, W. Heuwieser, D. Streyl, J. J. Bromfield, A. Miyamoto, C. Fergani, and H. Dobson. 2014. Innate immunity and inflammation of the bovine female reproductive tract in health and disease. Reproduction 148:R41R51.

Sheldon, I. M., G. S. Lewis, S. LeBlanc, and R. O. Gilbert. 2006 Defining postpartum uterine disease in cattle. Theriogenology 65:1516-1530.

Standen, B. T., M. D. Rawling, S. J. Davies, M. Castex, A. Foey, G. Gioacchini, O. Carnevali, and D. L. Merrifield. 2013. Probiotic Pediococcus acidilactici modulates both localised intestinal- and peripheral-immunity in tilapia (Oreochromis niloticus). Fish Shellfish Immunol. 35:1097-1104.

Vogel, V., and M. Sheetz. 2006. Local force and geometry sensing regulate cell functions. Nat. Rev. Mol. Cell Biol. 7:265-275.

Walker, C. G., S. Meier, H. Hussein, S. McDougall, C. R. Burke, J. R. Roche, and M. D. Mitchell. 2015. Modulation of the immune system during postpartum uterine inflammation. Physiol. Genomics 47:89-101.

Wathes, D. C., Z. Cheng, W. Chowdhury, M. A. Fenwick, R. Fitzpatrick, D. G. Morris, J. Patton, and J. J. Murphy. 2009. Negative energy balance alters global gene expression and immune responses in the uterus of postpartum dairy cows. Physiol. Genomics 39:1-13.

Williams, E. J., D. P. Fischer, D. U. Pfeiffer, G. C. England, D. E. Noakes, H. Dobson, and I. M. Sheldon. 2005. Clinical evaluation of postpartum vaginal mucus reflects uterine bacterial infection and the immune response in cattle. Theriogenology 63:102-117.

Woraprayote, W., Y. Kingcha, P. Amonphanpokin, J. Kruenate, T. Zendo, K. Sonomoto, S. Benjakul, and W. Visessanguan. 2013. Anti-listeria activity of poly(lactic acid)/sawdust particle biocomposite film impregnated with pediocin $\mathrm{PA}-1 / \mathrm{AcH}$ and its use in raw sliced pork. Int. J. Food Microbiol. 167:229-235.

Zhang, W., Y. H. Zhu, J. C. Yang, G. Y. Yang, D. Zhou, and J. F. Wang. 2015. A selected Lactobacillus rhamnosus strain promotes EGFR-independent Akt activation in an enterotoxigenic Escherichia coli K88-infected IPEC-J2 cell model. PLoS One 10:e0125717. 